\title{
Intensifikasi Pekarangan dengan Tanaman Obat sebagai Ecotherapy dan Peningkat Imunitas
}

\author{
Joko Sutrisno*, Agustono, Rhina Uchyani Fajarningsih, Refa'ul Khairiyakh, Amalia Nadifta Ulfa dan \\ Indah Nurhidayati
}

Program Studi Agribisnis, Fakultas Pertanian, Universitas Sebelas Maret, Surakarta, Indonesia

Diterima: 1 Juli 2021; Disetujui: 21 Juli 2021

\begin{abstract}
Abstrak
Corona Virus Disease 19 (COVID-19) merupakan penyakit yang disebabkan oleh virus SARS-CoV-2 yang dapat menular antar manusia melalui percikan batuk atau bersin. Penerapan protokol kesehatan dan peningkatan imunitas tubuh merupakan upaya yang dapat dilakukan untuk mencegah terjangkit COVID-19. Intensifikasi pekarangan dengan menggunakan tanaman obat peningkat imunitas memiliki beberapa manfaat yaitu pemenuhan kebutuhan rumah tangga terhadap tanaman obat peningkat imunitas, mengatasi melonjaknya harga tanaman obat peningkat imunitas, dan sebagai aktivitas fisik serta ecotherapy masyarakat dalam rangka meningkatkan imunitas. Pengabdian masyarakat dengan tema intensifikasi pekarangan dengan tanaman obat peningkat imunitas dan sebagai ecotherapy dilaksanakan di Kecamatan Mojolaban Kabupaten Sukoharjo. Kegiatan pengabdian bertujuan untuk meningkatkan pengetahuan dan keterampilan masyarakat terkait intensifikasi pekarangan dengan tanaman obat peningkat imunitas yang juga dapat digunakan sebagai sarana ecotherapy. Kegiatan ini dilakukan dengan metode penyuluhan dan pelatihan yang dilakukan kepada perwakilan dua Kelompok Wanita Tani (KWT) yakni KWT Sri Rejeki dan KWT Mekar Sari. Peserta kegiatan pengabdian terlihat antusias dalam mengikuti setiap tahapan kegiatan. Pada kegiatan pengabdian ini, tim pengabdi juga menyerahkan alat dan bahan berupa media tanam, pupuk, bibit tanaman obat yaitu kunyit, jahe, temulawak, dan serai kepada KWT Sri Rejeki dan KWT Mekar Sari untuk memulai gerakan intensifikasi pekarangan dengan tanaman obat peningkat imunitas. Kegiatan pengabdian ini meningkatkan pengetahuan masyarakat di Kecamatan Mojolaban tentang intensifikasi pekarangan terutama menggunakan tanaman obat, masyarakat juga antusias untuk melakukan kegiatan intensifikasi pekarangan dengan tanaman obat peningkat imunitas setelah mengetahui berbagai manfaat yang akan diperoleh.
\end{abstract}

Kata kunci: COVID-19; ecotherapy; imunitas; intensifikasi; tanaman obat

\section{Intensification of Home Garden with Medical Plants as Ecotherapy and Immunity Booster}

\begin{abstract}
Corona Virus Disease 19 (COVID-19) is a disease caused by the SARS-CoV-2 virus that can be transmitted between humans through coughing or sneezing. The application of health protocols and increased immunity is an effort to prevent COVID-19 infection. Intensification of home garden with immune-boosting medical plants have several benefits, that are the fulfillment of household needs of immune-boosting medical plants, overcome the soaring price of immune-boosting medical plants and as physical activity and community ecotherapy to increase immunity. Community service with theme

\footnotetext{
*Corresponding author: jokosutrisno@staff.uns.ac.id

Cite this as: Sutrisno, J., Agustono, Fajarningsih, R. U., Khairiyakh, R., Ulfa, A. N., \& Nurhidayati, I. (2021). Intensifikasi Pekarangan dengan Tanaman Obat sebagai Ecotherapy dan Peningkat Imunitas. AgriHealth: Journal of Agri-food, Nutrition and Public Health, 2(1), 45-54. doi: http://dx.doi.org/10.20961/agrihealth. v2i1.52719
} 
intensification of home garden with immune-boosting medical plants and as ecotherapy was carried out in Mojolaban Sub-district, Sukoharjo. The community service aimed to improve the knowledge and skills of the community related to the intensification of home garden medical plants that can be used as ecotherapy. This activity was conducted by extension and training methods to representatives of two Farmer Women's Groups, namely KWT Sri Rejeki and KWT Mekar Sari. Participants of this community activity look enthusiastic to follow each activity. The team of community service activity in Mojolaban Sub-district also handed over tools and materials in form of planting media, fertilizers, medical plants seed (turmeric, ginger, temulawak and lemongrass) to KWT Sri Rejeki and KWT Mekar Sari for starting the intensification of home garden with immune-boosting medical plants. This community service increases the knowledge of the community in Mojolaban Sub-district about the intensification of home gardens with immune-boosting medical plants, the community is also enthusiastic to conduct home garden intensification with immune-boosting medical plants after knowing of benefits that will be obtained.

Keywords: COVID-19; ecotherapy; herbal; immunities; intensification

\section{PENDAHULUAN}

Corona Virus Disease 2019 atau biasa disebut COVID-19 merupakan suatu penyakit yang menyebar sejak tahun 2019 yang disebabkan oleh virus SARS-CoV-2 (Pemerintah Sukoharjo, 2021). Menurut Kemenkes RI (2020), virus SARS-CoV-2 merupakan virus yang dapat ditularkan dari manusia ke manusia melalui percikan batuk atau bersin. Hal ini menyebabkan orang yang melakukan kontak erat dengan pasien COVID-19 memiliki risiko tinggi tertular virus $S A R S-C o V-2$.

Penyebaran virus $S A R S-C o V-2$ yang dapat terjadi dari manusia ke manusia menyebabkan tingkat kasus COVID-19 menjadi cepat meningkat. Kasus positif COVID-19 pertama di Indonesia diumumkan pada tanggal 2 Mei 2020. Berdasarkan data WHO, hingga Januari 2021 telah tercatat 1.037 .993 kasus terkonfirmasi dengan kasus kematian mencapai 29.331 di Indonesia (WHO, 2021). Sementara itu, untuk kasus lokal di Kabupaten Sukoharjo telah mencapai 3.890 kasus terkonfirmasi dengan 240 kasus kematian (Pemerintah Sukoharjo, 2021). Virus SARS-CoV-2 di Kabupaten Sukoharjo telah menyebar hampir di setiap kecamatan. Jumlah dan kepadatan penduduk yang tinggi di Kecamatan Mojolaban membuat Kecamatan Mojolaban harus lebih waspada terhadap penyebaran virus $S A R S-C o V-2$.

Berbagai upaya dilakukan pemerintah pusat dan daerah untuk menekan penyebaran virus SARS-CoV-2. Salah satu upaya yang dilakukan adalah melalui protokol kesehataan yang diterapkan di seluruh lapisan masyarakat.
Upaya lain yang dapat dilakukan oleh masyarakat untuk melindungi diri dari tertular virus SARS$\mathrm{CoV}-2$ adalah peningkatan sistem imunitas tubuh. Menurut Ika (2020), peningkatan sistem imunitas tubuh dapat dilakukan oleh masyarakat dengan cara mengonsumsi bahan pangan yang memiliki kandungan zat untuk meningkatkan imunitas, melakukan aktivitas fisik (olahraga) secara rutin, dan melakukan pengelolaan stres.

Jamu merupakan salah satu alternatif obat yang dapat dikonsumsi untuk meningkatkan imunitas. Hal ini karena jamu mengandung bahan pangan yang memiliki kandungan zat peningkat imunitas tubuh. Menurut Menteri Kesehatan Republik Indonesia (2010), jamu merupakan obat tradisional Indonesia, yaitu bahan atau ramuan bahan yang berupa bahan tanaman, bahan hewan, bahan mineral, sediaan sarian (galenik), atau campuran dari bahan tersebut yang secara turun temurun telah digunakan untuk pengobatan dan dapat diterapkan sesuai dengan norma yang berlaku di masyarakat. Tanaman yang biasa digunakan sebagai bahan pembuat jamu yang memiliki manfaat untuk meningkatkan imunitas tubuh antara lain jahe, kunyit, temulawak, dan serai.

Terjadinya pandemi COVID-19 di Indonesia telah membuat harga rempah-rempah mengalami peningkatan termasuk harga jahe, kunyit, temulawak, dan serai. Hal ini disebabkan oleh peningkatan permintaan akan tanaman obat. Masyarakat dapat mengatasi permasalahan tingginya harga tersebut dengan cara memproduksi sendiri berbagai tanaman obat tersebut dengan memanfaatkan pekarangan rumah. Menurut Ashari dan Purwanti (2012), 
pemanfaatan lahan pekarangan memiliki peran yang cukup penting yakni sebagai penyedia pangan dan gizi rumah tangga serta sebagai sumber pendapatan tambahan rumah tangga.

Intensifikasi pekarangan dengan menanam berbagai tanaman obat peningkat imunitas juga dapat berfungsi sebagai ecotherapy. Ecotherapy merupakan salah satu kegiatan yang dapat dilakukan untuk mengelola stres diri guna meningkatkan imunitas tubuh. Menurut Wilson et al. (2009), ecotherapy merupakan suatu intervensi yang menggunakan lingkungan hijau untuk meningkatkan fungsi psikologi. Sementara itu, Chalquist (2009) menyatakan bahwa ecotherapy adalah sebuah metode paying untuk sekumpulan teknik-teknik yang memimpin lingkaran penyembuhan saling menguntungkan antara pikiran manusia dengan dunia alam. Ecotherapy terdiri atas hortikultura terapi, manajemen waktu stres, terapi menggunakan hewan, dan kegiatan di alam bebas. Menurut Yasmine (2020), ecotherapy bermanfaat untuk meringankan stres akibat rutinitas sehari-hari, menjernihkan pikiran, meningkatkan kinerja sistem imunitas, meningkatkan suasana hati, dan meningkatkan kreativitas dan melatih panca indera.

Kecamatan Mojolaban merupakan salah satu kecamatan di Kabupaten Sukoharjo. Pada masa pandemi COVID-19, masyarakat Kecamatan Mojolaban juga menghadapi permasalahan seperti di daerah lainnya yakni bagaimana menjaga diri dan keluarga dari virus SARS $\mathrm{CoV}$-2. Peningkatan imunitas melalui konsumsi bahan pangan yang berkhasiat meningkatkan imunitas dan ecotherapy merupakan salah satu cara yang dapat dilakukan untuk menjaga diri dari virus $S A R S-C o V-2$.

Badan Pusat Statistik Kabupaten Sukoharjo (2019) menyebutkan bahwa Kecamatan Mojolaban memiliki lahan bukan lahan sawah yang digunakan sebagai pekarangan sebesar $89,1 \%$ dari total luas bukan lahan sawah. Berdasarkan data tersebut, Kecamatan Mojolaban memiliki potensi lahan yang merupakan peluang untuk mengimplementasikan intensifikasi pekarangan dengan menanam tanaman obat. Implementasi intensifikasi pekarangan dengan menggunakan tanaman obat bermanfaat untuk mengatasi peningkatan harga tanaman rempah di tengah masa pandemi, pemenuhan kebutuhan rumah tangga terhadap tanaman obat yang berkhasiat meningkatkan imunitas, serta sebagai salah satu bentuk ecotherapy bagi masyarakat. Kegiatan pengabdian di Kecamatan Mojolaban bertujuan untuk meningkatkan pengetahuan dan keterampilan masyarakat terkait intensifikasi pekarangan dengan tanaman obat peningkat imunitas yang juga dapat digunakan sebagai sarana ecotherapy.

\section{BAHAN DAN METODE}

Kegiatan pengabdian kepada masyarakat dilaksanakan di Desa Wirun, Kecamatan Mojolaban Kabupaten Sukoharjo. Kegiatan ini bekerja sama dengan TP PKK Desa Wirun yang terdiri dari dua Kelompok Wanita Tani (KWT) yaitu KWT Sri Rejeki dan KWT Mekar Sari. Pelaksanaan kegiatan pengabdian kepada masyarakat dibagi menjadi empat tahapan kegiatan sebagai berikut: (1) sosialisasi dan koordinasi kegiatan, (2) penyuluhan terkait intensifikasi pekarangan, (3) pelatihan dan praktik penanaman, serta (4) monitoring dan evaluasi kegiatan.

Pelaksanaan kegiatan tahap satu yaitu sosialisasi dan koordinasi kegiatan dilaksanakan pada tanggal 16 Juni 2021. Kegiatan tahap satu dilaksanakan oleh perwakilan tim pengabdi dan tim TP PKK Desa Wirun. Kegiatan ini dilaksanakan untuk menentukan jadwal pelaksanaan kegiatan pengabdian dan hal-hal terkait pelaksanaan kegiatan pengabdian.

Tahap dua dan tiga dilaksanakan pada tanggal 23 Juni 2021 pukul 13.00 WIB hingga 14.30 WIB. Lokasi pelaksanaan kegiatan adalah balai Desa Wirun, Kecamatan Mojolaban, Kabupaten Sukoharjo. Kegiatan pengabdian menggunakan metode penyuluhan dan praktik langsung. Kegiatan dilaksanakan dengan melakukan pembatasan jumlah orang dan melaksanakan protokol kesehatan. Pembatasan jumlah orang yang berkumpul dilakukan dengan cara membatasi jumlah tim pengabdi yang mana tim pengabdi hanya mengirimkan perwakilan serta membatasi jumlah undangan pengabdian dimana TP PKK Desa Wirun hanya diwakili oleh lima orang perwakilan dari KWT Sri Rejeki dan lima orang perwakilan dari KWT Mekar Sari. Protokol kesehatan dilaksanakan dengan menyediakan tempat cuci tangan di area pelaksanaan kegiatan, memberikan hand sanitizer, masker, dan face shield kepada setiap orang yang terlibat di dalam kegiatan. Tahap empat kegiatan akan 
dilaksanakan tiga bulan setelah kegiatan pelatihan.

Kegiatan tahap empat yaitu evaluasi dan monitoring akan dilakukan secara daring. Hal ini dikarenakan untuk membatasi pertemuan dengan masa yang banyak. Kegiatan akan dilaksanakan menggunakan aplikasi WhatsApp dan Zoom meeting.

\section{HASIL DAN PEMBAHASAN}

Pekarangan dapat dianggap sebagai suatu lingkungan mikro dalam agroekosistem yang melestarikan fungsi dan ketahanan ekosistem yang lebih besar. Pekarangan dideskripsikan sebagai sebuah sistem agroforestri yang berkelanjutan dengan fitur ekologi dan sosial ekonomi yang positif. Pekarangan memiliki nilai keberlanjutan yang tinggi. Nilai keberlanjutan ini dapat dilihat dimana pekarangan dapat memenuhi prinsip-prinsip keberlanjutan baik secara ekologi maupun sosial. Meskipun memiliki nilai keberlanjutan, fungsi dan komposisi suatu pekarangan sangat tergantung pada kondisi sosial ekonomi serta strategi mata pencaharian rumah tangga tani pemiliknya (Engels, 2002; Wiersum, 2006). Sementara itu, Kurnianingsih (2013) menyatakan bahwa secara sederhana pekarangan merupakan lahan terbuka yang berada di sekitar rumah tinggal. Pekarangan dapat dimanfaatkan untuk berbagai macam aktivitas, salah satunya adalah untuk menanam tanaman produktif seperti tanaman obat yang memiliki khasiat untuk meningkatkan imunitas tubuh manusia.

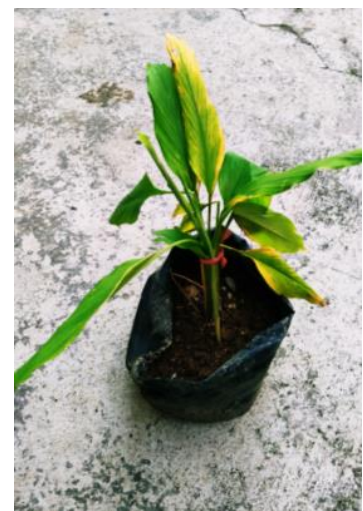

a.

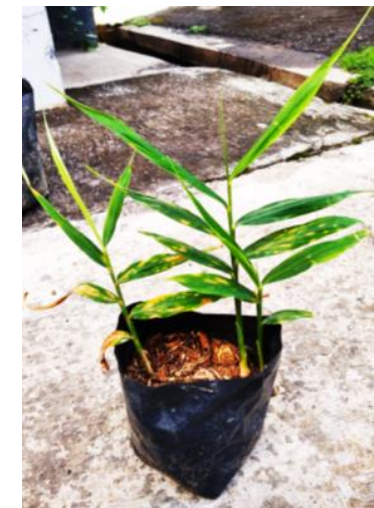

b.

Pemanfaatan pekarangan atau intensifikasi pekarangan merupakan salah satu aktivitas yang dapat dilakukan di tengah pandemi COVID-19. Menurut Pambudi (2020), pemanfaatan lahan pekarangan secara tepat baik dalam pemilihan jenis tanaman dan pola tanam yang dilakukan akan sangat berkontribusi pada ketahanan kesehatan dan pangan harian nonberas rumah tangga. Tanaman obat merupakan salah satu tanaman yang dapat digunakan untuk intensifikasi pekarangan. Menurut Silveira et al. (2020), terdapat beberapa obat herbal yang dapat digunakan untuk membantu mengatasi gejala COVID-19 diantaranya Althaea officinalis, Commiphora molmol, Glycyrrhiza glabra, Hedera helix, dan Sambucus nigra.

Di Indonesia, terdapat tanaman obat yang dipercaya dapat meningkatkan imunitas tubuh karena berbagai kandungan yang terdapat di dalamnya. Memanfaatkan pekarangan dengan menanam tanaman obat yang memiliki khasiat peningkat imunitas tentunya memiliki manfaat besar bagi masyarakat seperti sebagai alternatif dalam mengatasi peningkatan harga dan pemenuhan kebutuhan rumah tangga terhadap tanaman tersebut. Lebih jauh, Widianarko (2020) menjelaskan bahwa beraktivitas di pekarangan merupakan suatu kegiatan ecotherapy yang bermanfaat untuk kebugaran badan, ketenangan jiwa, dan kejernihan pikiran. Tanaman obat yang digunakan untuk intensifikasi pekarangan di Kecamatan Mojolaban Kabupaten Sukoharjo pada kegiatan pengabdian kepada masyarakat adalah jahe, kunyit, temulawak, dan serai (Gambar 1).

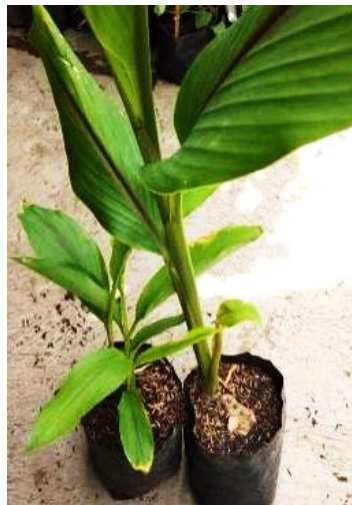

C.

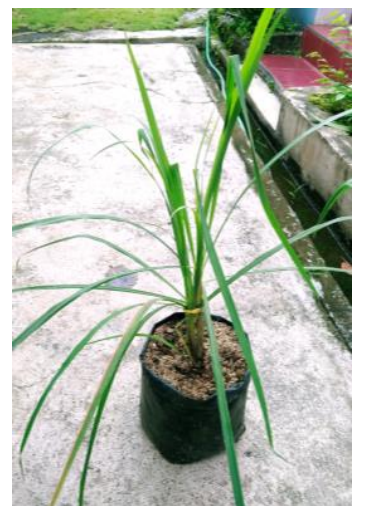

d.

Gambar 1. Tanaman a.) Kunyit; b.) Jahe; c.) Temulawak; dan d.) Serai

Pemilihan keempat tanaman tersebut pada kegiatan pengabdian kepada masyarakat di
Kecamatan Mojolaban Kebupaten Sukoharjo adalah (1) jahe, kunyit, temulawak, dan serai 
merupakan tanaman obat (rempah-rempah) yang sering digunakan sebagai bumbu dapur dan bahan jamu (obat tradisional) oleh masyarakat, (2) jahe, kunyit, temulawak, dan serai merupakan tanaman obat (rempah) yang memiliki kandungan untuk meningkatkan imunitas tubuh, dan (3) tanaman tersebut dapat ditata sedemikian rupa sehingga dapat memberikan pemandangan hamparan yang indah guna ecotherapy selain kegiatan berkebun itu sendiri. Adapun kandungan dan manfaat keempat tanaman tersebut dirincikan pada Tabel 1.

Tabel 1. Kandungan dan manfaat kunyit, jahe, temulawak, dan serai

\begin{tabular}{|c|c|c|}
\hline Nama bahan & Kandungan utama & Manfaat \\
\hline Kunyit & $\begin{array}{l}\text { Kurkuminoid, desmetoksikumin, } \\
\text { dan bisdesmetoksikurkumin }\end{array}$ & $\begin{array}{l}\text { Antioksidan, antitumor dan anti kanker, anti } \\
\text { pikun, penurun kadar lemak dan kolesterol } \\
\text { dalam darah, antimikroba, antiseptik, dan } \\
\text { antiinflamasi }\end{array}$ \\
\hline Jahe & $\begin{array}{l}\text { Vitamin C, magnesium, gingerols, } \\
\text { shagaols, dan zingerones }\end{array}$ & $\begin{array}{l}\text { Anti-inflamasi, antioksidan, pereda nyeri haid, } \\
\text { menurunkan glukosa darah, memperkuat sistem } \\
\text { imunitas, menangkal infeksi bakteri dan virus }\end{array}$ \\
\hline Temulawak & $\begin{array}{l}\text { Karbohidrat, serat, protein, lemak, } \\
\text { kurkumin, kalium, kalsium, fenol, } \\
\text { flavonoid }\end{array}$ & $\begin{array}{l}\text { Anti-inflamasi, antikanker, penyembuh luka, } \\
\text { menurunkan kadar kolesterol serum, dan } \\
\text { meningkatkan imunitas }\end{array}$ \\
\hline Serai & $\begin{array}{l}\text { Vitamin A, vitamin C, karbohidrat, } \\
\text { protein, folat, riboflavin, zat besi, }\end{array}$ & $\begin{array}{l}\text { Anti-inflamasi dan menurunkan intensitas nyeri } \\
\text { haid, memelihara daya tahan tubuh }\end{array}$ \\
\hline
\end{tabular}
magnesium, mangan, seng

Sumber: (Kurniawati, 2010; Dewi et al., 2012; Hartati, 2013; Royhanaty et al., 2018; Redi Aryanta, 2019; Syamsudin et al., 2019; Artasya and Parapasan, 2020)

Kegiatan pengabdian di Kecamatan Mojolaban Kabupaten Sukoharjo dilakukan di Desa Wirun dengan peserta yang merupakan perwakilan dua KWT. Persiapan kegiatan dilakukan oleh tim pengabdi dengan menyiapkan alat dan bahan seperti bibit tanaman jahe, kunyit, temulawak, dan serai, menyiapkan media tanam dan polybag, menyiapkan modul penyuluhan dan pelatihan intensifikasi pekarangan yang memuat manfaat, cara tanam, pemeliharaan, panen, dan beberapa cara pengolahan untuk setiap tanaman obat, menyiapkan alat untuk menerapkan protokol kesehatan seperti masker, face shield, hand sanitizer, thermogun, tempat pencuci tangan, dan sabun cuci tangan.

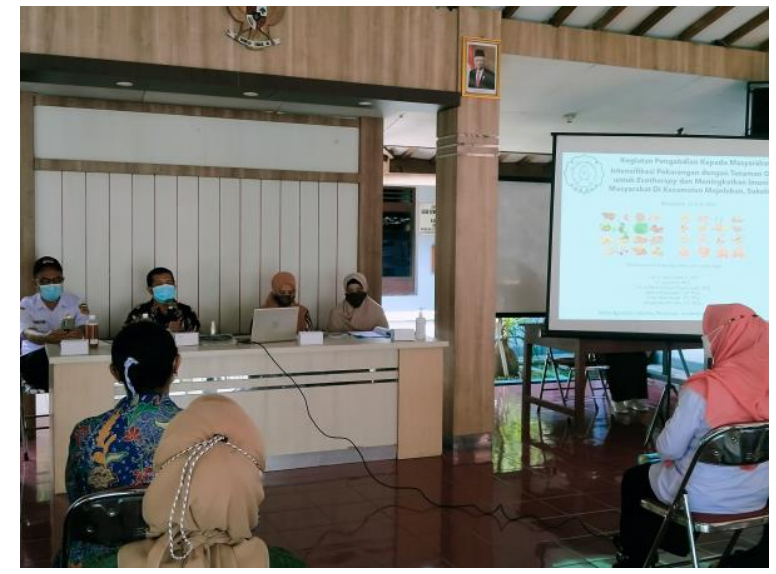

a.

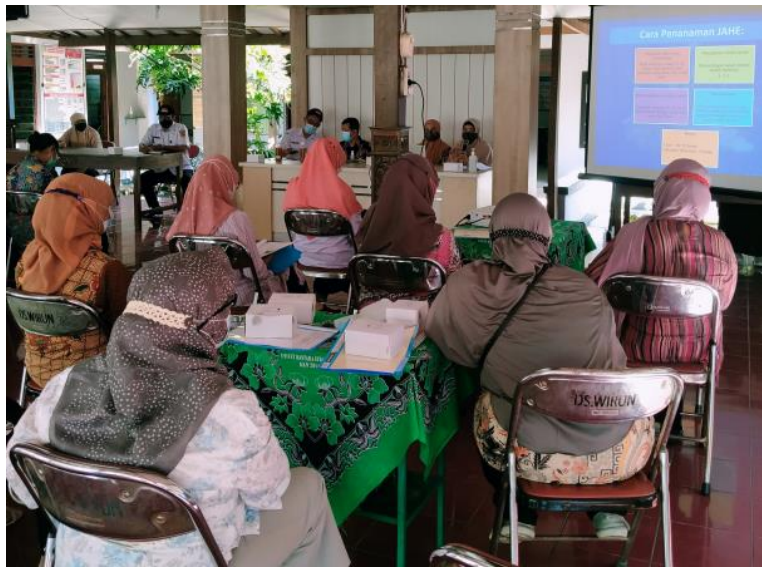

b.

Gambar 2. a.) Dokumentasi kegiatan penyuluhan (penyampaian materi) dan b.) peserta intensifikasi pekarangan dengan menggunakan tanaman obat

Pelaksanaan kegiatan pengabdian kepada masyarakat di Kecamatan Mojolaban Kabupaten
Sukoharjo dilakukan dengan menerapkan protokol kesehatan, yaitu pembatasan jumlah 
peserta, himbauan mencuci tangan sebelum memasuki tempat kegiatan, pengecekan suhu tubuh peserta dan tim pengabdi, memakai Alat Pelindung Diri (APD) seperti masker dan atau face shield bagi peserta dan tim pengabdi, serta melaksanakan jaga jarak pada saat kegiatan berlangsung. Kegiatan pengabdian dimulai dengan sambutan penerimaan dari Kepala Desa Wirun Kecamatan Mojolaban Kabupaten Sukoharjo bernama Bapak Erry Suseno Wibowo, SE. Kegiatan dilanjutkan dengan penyuluhan materi intensifikasi pekarangan dengan menanam tanaman obat yang berguna untuk meningkatkan imunitas dan sebagai sarana ecotherapy oleh tim pengabdi (Gambar 2).
Penyuluhan pertanian bertujuan untuk mengubah pengetahuan keterampilan dan sikap petani (Hasan et al., 2016). Kegiatan penyuluhan pengabdian ini bertujuan untuk meningkatkan pengetahuan dan keterampilan peserta kegiatan dalam hal ini adalah KWT yang ada di Desa Wirun Kecamatan Mojolaban Kabupaten Sukoharjo mengenai intensifikasi pekarangan dengan menggunakan tanaman obat. Kegiatan pengabdian dilanjutkan dengan pelatihan terkait intensifikasi pekarangan dalam hal ini pelatihan penanaman, pemeliharaan, dan cara panen untuk tanaman jahe, kunyit, temulawak, dan serai. Adapun rangkaian kegiatan penanaman, pemeliharaan, dan panen untuk keempat tanaman tersebut dijabarkan dalam Tabel 2.

Tabel 2. Tata cara penanaman, pemeliharaan, dan panen tanaman kunyit, jahe, temulawak, dan serai

\begin{tabular}{|c|c|c|c|}
\hline Nama tanaman & Penanaman & Pemeliharaan & Panen \\
\hline Kunyit & $\begin{array}{l}\text { 1. Memilih bibit kunyit dari } \\
\text { indukan yang bagus dengan } \\
\text { umur } 7-12 \text { bulan } \\
\text { 2. Penyemaian rimpang } \\
\text { dilakukan dengan } \\
\text { meletakkan rimpang diatas } \\
\text { tanah yang lembap dan } \\
\text { tidak terkena sinar matahari } \\
\text { langsung } \\
\text { 3. Ambil tunas pada rimpang } \\
\text { semaian jika sudah } \\
\text { mencapai } 10 \mathrm{~cm} \\
\text { 4. Pindahkan bibit ke media } \\
\text { tanam (campuran tanah } \\
\text { gembur, kompos, dan } \\
\text { pupuk kandang dengan } \\
\text { perbandingan } 2: 1: 1 \text { ) }\end{array}$ & $\begin{array}{l}\text { 1. Lakukan pemupukan } \\
\text { dengan pupuk kandang } \\
\text { dan pupuk kompos } \\
\text { (1:1) } \\
\text { 2. Penyiraman dilakukan } \\
\text { setidaknya } 2 \text { atau } 3 \\
\text { hari sekali }\end{array}$ & $\begin{array}{l}\text { Kunyit dapat dipanen } \\
\text { setelah berusia } 7-8 \\
\text { bulan }\end{array}$ \\
\hline Jahe & $\begin{array}{l}\text { 1. Pilihlah bibit berkualitas } \\
\text { yaitu yang berasal dari } \\
\text { kebun dan berumur antara } \\
\text { 9-10 bulan } \\
\text { 2. Menyiapkan media } \\
\text { tanaman berupa campuran } \\
\text { tanah, sekam, dan pupuk } \\
\text { kandang }(1: 1: 1) \\
\text { 3. Lakukan penyemaian bibit } \\
\text { jahe } \\
\text { 4. Pindahkan rimpang jahe } \\
\text { yang sudah bertunas pada } \\
\text { media tanam }\end{array}$ & $\begin{array}{l}\text { 1. Siram jahe dengan air } \\
\text { secukupnya dan } \\
\text { pastikan air tidak } \\
\text { menggenang } \\
\text { 2. Pada usia jahe } 2 \\
\text { minggu, taburkan anti } \\
\text { jamur untuk mencegah } \\
\text { jamur pada tanaman }\end{array}$ & $\begin{array}{l}\text { Jahe siap dipanen } \\
\text { setelah usia 10-12 } \\
\text { bulan. Namun, jika } \\
\text { diperuntukan sebagai } \\
\text { bumbu dapur atau } \\
\text { minuman, jahe dapat } \\
\text { dipanen pada usia } 4 \\
\text { bulan }\end{array}$ \\
\hline Temulawak & $\begin{array}{l}\text { 1. Pemilihan benih dari } \\
\text { varietas jelas dengan umur } \\
\text { indukan } 10 \text { bulan }\end{array}$ & $\begin{array}{l}\text { 1. Pada awal penanaman } \\
\text { lakukan penyiraman } \\
\text { setiap pagi dan sore } \\
\text { hari }\end{array}$ & $\begin{array}{l}\text { Panen temulawak } \\
\text { dapat dilakukan setelah } \\
\text { tanaman berusia } 8-10 \\
\text { bulan }\end{array}$ \\
\hline
\end{tabular}


Tabel 2. Lanjutan

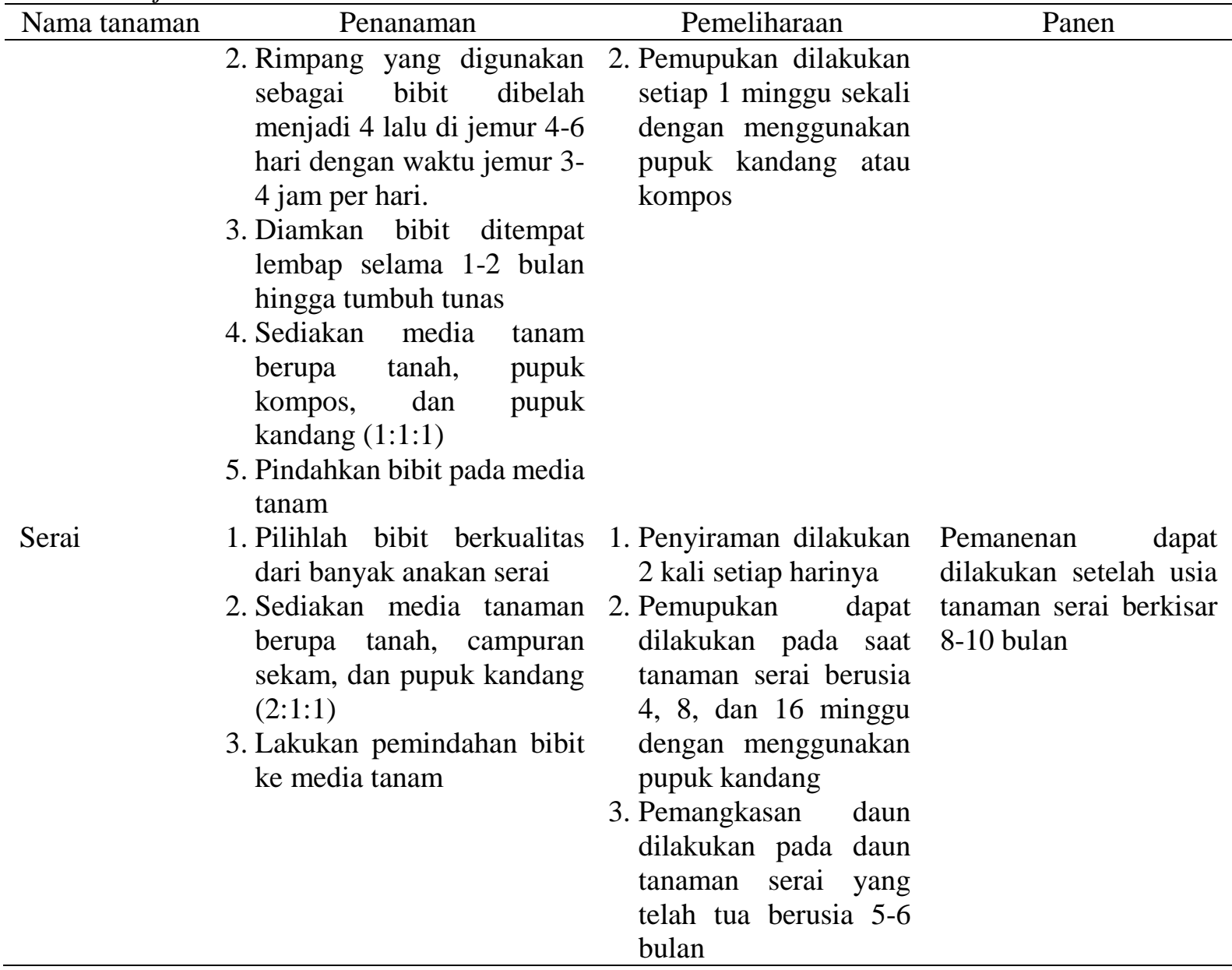

Sumber: (Rahardjo dan Rostiana, 2005, 2014; Kementerian Pertanian, 2019; Kementerian Pertanian, 2019; Qomariah, 2021)

Pelatihan tersebut bertujuan agar peserta dapat melakukan penanaman, pemeliharaan, dan panen dengan baik dan benar. Setelah kegiatan pelatihan berakhir, kegiatan pengabdian dilanjutkan dengan penyerahan bantuan alat dan bahan alat dan bahan yang dapat digunakan KWT untuk memulai intensifikasi pekarangan seperti bibit jahe, kunyit, temulawak, dan serai (Gambar 3). Peserta kegiatan terlihat antusias mengikuti seluruh rangkaian kegiatan pengabdian (Gambar 4).

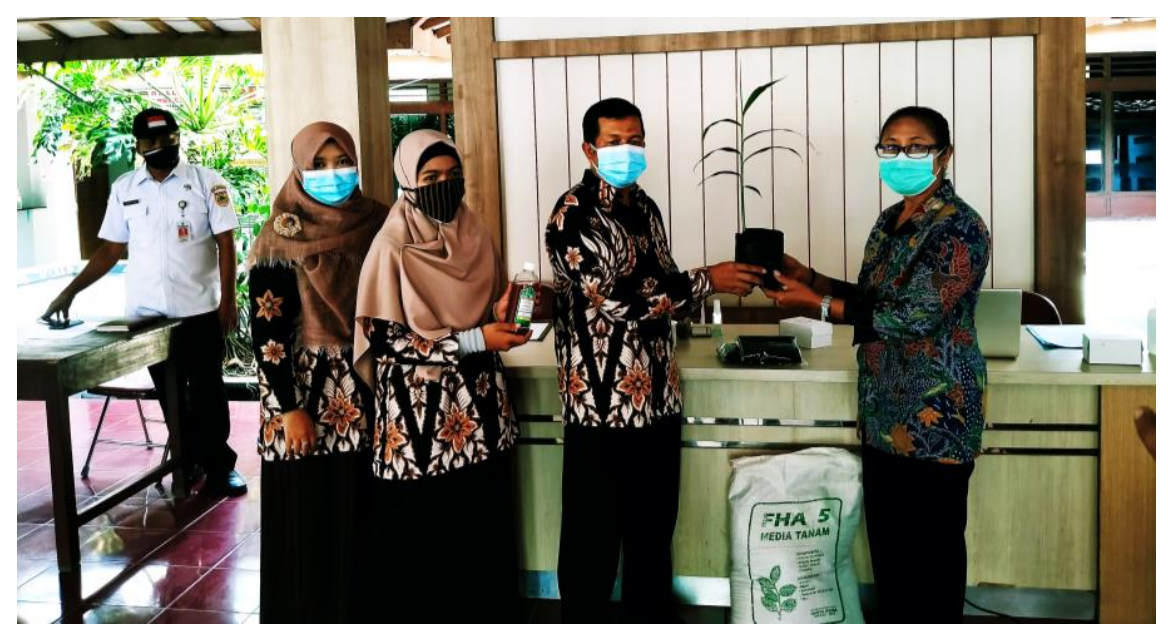

Gambar 3. Penyerahan bantuan alat dan bahan untuk memulai kegiatan intensifikasi pekarangan 


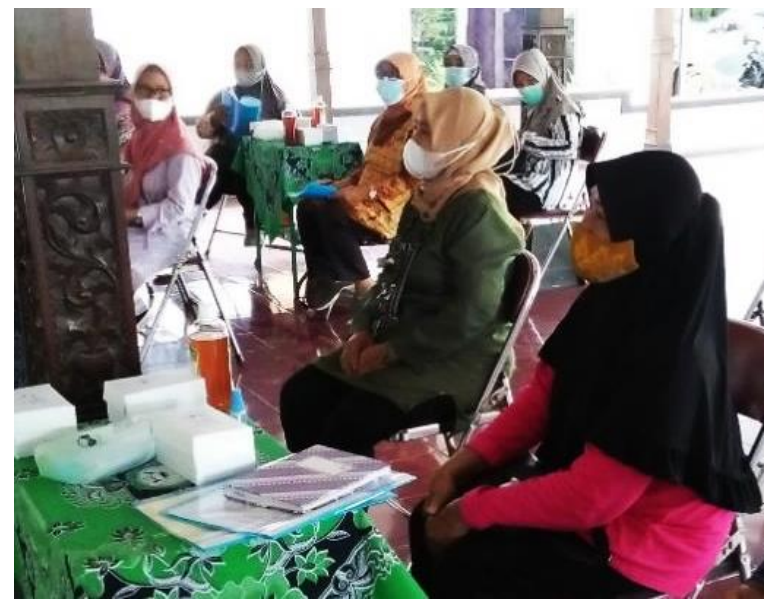

Gambar 4. Antusias peserta dalam mengikuti rangkaian kegiatan

\section{KESIMPULAN}

Kegiatan intensifikasi pekarangan menggunakan tanaman obat yang berguna untuk meningkatkan imunitas diharapkan merupakan salah satu cara untuk mengatasi kenaikan harga tanaman obat tersebut dan untuk pemenuhan kebutuhan rumah tangga. Kegiatan pengabdian diharapkan dapat bermanfaat sebagai ecotherapy bagi masyarakat. Peserta kegiatan pengabdian kepada masyarakat di Kecamatan Mojolaban Kabupaten Sukoharjo antusias melaksanakan rangkaian kegiatan pengabdian dengan tema intensifikasi pekarangan menggunakan tanaman obat yang berguna untuk meningkatkan imunitas dan sebagai ecotherapy.

\section{UCAPAN TERIMA KASIH}

Penulis menyampaikan terima kasih kepada Universitas Sebelas Maret sebagai pemberi dana program pengabdian kepada masyarakat "Intensifikasi Pekarangan dengan Tanaman Obat untuk Ecotherapy dan Meningkatkan Imunitas Masyarakat di Kecamatan Mojolaban, Sukoharjo" skim Pengabdian Kepada Masyarakat Hibah Group Riset (PKM HGR-UNS) dengan Surat Kontrak Nomor 349.1/UN27/HK/2021 tahun kegiatan 2021. Penulis juga menyampaikan terima kasih kepada pemerintah Desa Wirun Kecamatan Mojolaban Kabupaten Sukoharjo atas perizinan dan penggunaan balai desa sebagai tempat pelaksanaan kegiatan pengabdian. Penulis menyampaikan terima kasih kepada para peserta kegiatan yaitu perwakilan KWT Sri Rejeki dan KWT Mekar Sari atas antusiasme dalam mengikuti rangkaian acara kegiatan pengabdian.

\section{DAFTAR PUSTAKA}

Artasya, R., \& Parapasan, S. (2020). Ginger as Anti-Inflammatory. Jurnal Penelitian Perawat Profesional, 2(3), 309-316. Retrieved from http://jurnal.globalhealthsciencegroup.com/in dex.php/JPPP/article/download/83/65

Ashari, \& Purwanti, T. B. (2012). Potensi dan prospek pemanfaatan pekarangan untuk mendukung ketahanan pangan. Forum Penelitian Agro Ekonomi, 30(1), 13-30. Tersedia dari https://media.neliti.com/media/ publications/62886-ID-potensi-dan-prospekpemanfaatan-lahan-pe.pdf

Badan Pusat Statistik Kabupaten Sukoharjo. (2019). Luas lahan bukan sawan menurut kecamatan dan status lahan. Tersedia dari https://sukoharjokab.bps.go.id/indicator/153/1 46/1/luas-lahan-bukan-sawah-menurut-kecam atan-dan-status-lahan.html

Chalquist, C. (2009). A Look at the ecotherapy research evidence. Ecopsychology, 1(2), 6475. https://doi.org/10.1089/eco.2009.0003

Dewi, M., Aries, M., Hardinsyah, Dwiriani, C. M., \& Januwati, N. (2012). Pengetahuan tentang manfaat kesehatan temulawak (Curcuma xanthorrhiza.) serta uji klinis pengaruhnya pada sistem imun humoral pada dewasa obes (Knowledge on health benefit of curcuma and the clinical trial of its effect on humoral immune system in obese A. Jurnal Ilmu Pertanian Indonesia (JIPI), Desember, 17(3), 166-171. Tersedia dari https://journal.ipb.ac.id/index.php/JIPI/article/ view/8337 
Engels, J. (2002). Home Gardens-a Genetic Resources Perspective. In J. Watson \& P. Eyzaguirre (Eds.), Home gardens and in situ Conservation of Plant Genetic Resources in Farming Systems (p. 3). Rome: International Plant Genetic Resources Institute. Tersedia dari https://www.bioversityinternational.org/ fileadmin/_migrated/uploads/tx_news/Home_ gardens_and_in_situ_conservation_of_plant_ genetic_resources_in_farming_systems_753. pdf

Hartati, S. Y. (2013). Khasiat kunyit sebagai obat tradisional dan manfaat lainnya. Warta Penelitian Dan Pengembangan Tanaman Industri, 19(2), 5-9. Tersedia dari https:// perkebunan.litbang.pertanian.go.id/wp-conten t/uploads/2014/02/Perkebunan_KhasiatKunyit .pdf

Hasan, S., Tilaar, W., \& Karamoy, L. T. (2016). Pengaruh penyuluhan pertanian dalam aspek lingkungan, ekonomi dan teknologi pada petani padi sawah di Kecamatan Modayag. Agri-SosioEkonomi Unsrat, 12(3), 165-178. https://doi.org/10.35791/agrsosek.12.3A.2016 .14388

Ika. (2020). Jurus tingkatkan imunitas tubuh saat pandemi COVID-19. Universitas Gadjah Mada. Tersedia dari https://ugm.ac.id/id/ berita/19310-jurus-tingkatkan-imunitas-tubuh -saat-pandemi-COVID-19

Kemenkes RI. (2020). Buku Pedoman Pencegahan dan Pengendalian COVID-19. Jakarta: Kemenkes RI. Tersedia dari https:// infeksiemerging.kemkes.go.id/document/dow nload/KpvOAX9r3j

Kementerian Pertanian. (2019). Standar Operasional Prosedur (SOP) Budidaya Kunyit. Jakarta: Kementerian Pertanian. Tersedia dari http://hortikultura.pertanian.go. id/wp-content/uploads/2019/06/SOP-BUDID AYA-KUNYIT-CET-3.pdf

Kementerian Pertanian. (2019). Budidaya Jahe. Jakarta: Kementerian Pertanian. Tersedia dari http://hortikultura.pertanian.go.id/wp-content/ uploads/2019/06/SOP-JAHE-KARANGANY AR-2019.pdf

Kurnianingsih, A. (2013). Optimalisasi lahan pekarangan dengan budidaya tanaman lidah buaya yang berkhasiat obat di Desa Purna Jaya
Kecamatan Indralaya Utara Kabupaten Ogan Ilir. Jurnal Pengabdian Sriwijaya, 1(1), 2124. https://doi.org/10.37061/jps.v1i1.1545

Kurniawati. (2010). Sehat dan cantik alami berkat bumbu dapur. Bandung: Mizan Pustaka. Tersedia dari https://scholar.google.co.id/ scholar?cites $=8667066084430517776 \&$ as_sdt $=2005 \&$ sciodt $=0,5 \&$ hl $=$ id \&authuser $=3$

Menteri Kesehatan Republik Indonesia. (2010). Peraturan Menteri Kesehatan Republik Indonesia Nomor: 003/Menkes/PER/I/2010 tentang Saintifikasi Jamu dalam Penelitian Berbasis Pelayanan Kesehatan. Indonesia: Kemenkes RI. Tersedia dari http://www.b2p2toot.litbang.kemkes.go.id/te muLAWAK/editor/tinymce/uploaded/DIP/P MK\%20No.003\%20ttg\%20Saintifikasi\%20Ja mu\%20Dalam\%20Penelitian\%20Berbasis\%2 0Pelayanan\%20Kesehatan.pdf

Pambudi, P. A. (2020). Pandemi COVID-19: refleksi pentingnya optimasi lahan pekarangan sebagai penyokong kemandirian pangan dan kesehatan keluarga. EnviroScienteae, 16(3), 408. https://doi.org/10.20527/es.v16i2.9683

Pemerintah Sukoharjo. (2021). Sukoharjo tanggap COVID-19. Tersedia dari https:// corona.sukoharjokab.go.id/

Qomariah, R. (2021). Serai dapur (Cymbopogon citratus) kaya manfaat, gampang budidayanya, dan bernilai ekonomi. Tersedia dari http://kalsel.litbang.pertanian.go.id/ind/in dex.php?option=com_content $\&$ view $=$ article $\&$ $\mathrm{id}=1017$ :ir-retna-qomariah-msi\&catid=14:alsi n\&Itemid $=43$

Rahardjo, M., \& Rostiana, O. (2005). Budidaya tanaman kunyit. Jakarta: Badan Penelitian dan Pengembangan Pertanian Balai Penelitian Tanaman Obat dan Aromatik. Tersedia dari https://scholar.google.co.id/scholar?cites $=178$ $72420818561885289 \&$ as_sdt $=2005 \&$ sciodt $=$ $0,5 \&$ hl $=$ id \&authuser $=3$

Rahardjo, M., \& Rostiana, O. (2014). Standar prosedur operasional budidaya temulawak. Jakarta: Badan Penelitian dan Pengembangan Pertanian Balai Penelitian Tanaman Obat dan Aromatik. Tersedia dari https://scholar.google. co.id/scholar?cites $=857893498709559662 \&$ a s_sdt=2005\&sciodt $=0,5 \& \mathrm{hl}=\mathrm{id} \&$ authuser $=3$ 
Redi Aryanta, I. W. (2019). Manfaat jahe untuk kesehatan. Widya Kesehatan, 1(2), 39-43. https://doi.org/10.32795/widyakesehatan.v1i2 .463

Royhanaty, I., Mayangsari, D., \& Novita, M. (2018). Manfaat minuman serai (Cymbopogo citrus) dalam menurunkan intensitas dismenore. Jurnal SMART Kebidanan, 5(1), 37. https://doi.org/10.34310/ sjkb.v5i1.153

Silveira, D., Prieto-Garcia, J. M., Boylan, F., Estrada, O., Fonseca-Bazzo, Y. M., Jamal, C. M., Magalhães, P. O., Pereira, E. O., Tomczyk, M., \& Heinrich, M. (2020). COVID-19: is there evidence for the use of herbal medicines as adjuvant symptomatic therapy? Frontiers in Pharmacology, 11(September), 1-44. https:// doi.org/10.3389/fphar.2020.581840

Syamsudin, R. A. M. R., Perdana, F., Mutiaz, F. S., Galuh, V., Rina, A. P. A., Cahyani, N. D., Aprilya, S., Yanti, R., Khendri, F. (2019). Review: tanaman temulawak (Curcuma xanthorrhiza Roxb) sebagai obat tradisional. Jurnal Ilmiah Farmako Bahari, 10(1), 51-65. Tersedia dari https://journal.
uniga.ac.id/index.php/JFB/article/view/648

WHO. (2021). WHO COVID-19 Homepagel Indonesia. Tersedia dari https://COVID19. who.int/region/searo/country/id

Widianarko, B. (2020). Pekarangan, eskapisme ekologis. Tersedia dari https://news.unika.ac. $\mathrm{id} / 2020 / 11 /$ pekarangan-eskapisme-ekologis/

Wiersum, K. F. (2006). Diversity and change in homegarden cultivation in Indonesia. In Tropical Homegardens: A Time-Tested Example of Sustainable Agroforestry (pp. 1324). Netherlands: Springer. https://doi.org/ 10.1007/978-1-4020-4948-4_2

Wilson, N., Ross, M., Lafferty, K., \& Jones, R. (2009). A review of ecotherapy as an adjunct form of treatment for those who use mental health services. Journal of Public Mental Health, 7(3), 23-35. https://doi.org/10.1108/ 17465729200800020

Yasmine, D. (2020). Manfaat ecotherapy untuk kesehatan fisik dan mental. Tersedia dari https://indonesiatatler.com/wellness/5-manfa at-ecotherapy-untuk-kesehatan-fisik-danmental 